\title{
Melatonin Receptor 1 Deficiency Affects Feeding Dynamics and Pro-Opiomelanocortin Expression in the Arcuate Nucleus and Pituitary of Mice
}

\author{
Claudia Fischer ${ }^{a, b}$ Tanja Mueller $^{a}$ Martina Pfeffer ${ }^{a, b}$ Helmut Wicht ${ }^{a}$ \\ Charlotte von Gall ${ }^{c}$ Horst-Werner Korfa, \\ ${ }^{a}$ Dr. Senckenbergische Anatomie, Institut für Anatomie II, and ${ }^{b}$ Dr. Senckenbergisches Chronomedizinisches \\ Institut, Johann-Wolfgang-Goethe-Universität, Frankfurt/Main, and ' Institut für Anatomie II, Medizinische Fakultät, \\ Heinrich-Heine-Universität, Düsseldorf, Germany
}

\section{Key Words}

Pro-opiomelanocortin $\cdot$ Melatonin receptor $1 \cdot$ Arcuate nucleus $\cdot$ Melatonin $\cdot$ Neuropeptide $Y$

\begin{abstract}
Background/Methods: Melatonin, the neurohormone for darkness, mediates photoperiod-dependent changes in physiology and behavior by targeting specific membranebound receptors (MT1 and MT2). In the present study, we investigated the impact of $\mathrm{MT} 1$ receptor deficiency on feeding behavior, locomotor activity and mRNA expression levels encoding for the polypeptide pro-opiomelanocortin (Pomc) and neuropeptide $\mathrm{Y}$ (Npy) in the hypothalamic arcuate nucleus (ARC) and the adenohypophysis [pars distalis (PD) and pars intermedia (PI)] in a comparison between wild-type (WT) and MT1-deficient (MT1-/-) mice. Results: The MT1-/- mice spent significantly more time feeding than the WT mice, while the general locomotor behavior, body weight and the total amount of food consumed did not differ between both genotypes. The nocturnal expression levels of Pomc in the ARC and PD were significantly higher in WT as compared to MT1-/- mice and exogenous melatonin administered during
\end{abstract}

\section{KARGER}

E-Mail karger@karger.com www.karger.com/nen
This article is licensed under the Creative Commons AttributionNonCommercial-NoDerivatives 4.0 International License (CC BYNC-ND) (http://www.karger.com/Services/OpenAccessLicense) tribution of modified material requires written permission.
trion the light phase stimulated Pomc expression in WT mice only. No differences were found between WT and MT1-/- mice with regard to Pomc expression levels in the PI. Conclusion: Thus, the MT1-mediated signaling stimulates Pomc expression in a region-specific pattern. Since the MT1-mediated changes in Pomc expression do not elicit direct orexigenic or anorexigenic effects, such effects are obviously mediated by regulatory systems downstream of the Pomc mRNA (e.g. cleavage and release of POMC derivatives), which are independent of MT1 signaling.

(C) 2016 The Author(s)

Published by S. Karger AG, Basel

\section{Introduction}

Metabolic functions follow circadian and seasonal rhythms. Melatonin, the neurohormone of darkness produced in and secreted from the pineal organ, is a key messenger for the phase and the length of the night and trans-

Dedicated to Prof. Andreas Oksche, Giessen, on the occasion of his 90th birthday. C.v.G. and H.-W.K. contributed equally to this work.

Claudia Fischer

Dr. Senckenbergische Anatomie

Institut für Anatomie II und Chronomedizinisches Institut

Theodor-Stern-Kai 7, DE-60590 Frankfurt/Main (Germany)

E-Mail C.Fischer@med.uni-frankfurt.de 
duces photoperiodic information [1] influencing the functional activity of the mediobasal hypothalamus and the adenohypophysis [2-4]. In general, melatonin can act upon two high-affinity melatonin receptors, MT1 and MT2 (formerly Mel1a and Mel1b) [5-8]. However, several studies suggest that it is mainly the MT1 receptor which mediates melatonin signaling to the hypothalamohypophysial axis [9-14].

The arcuate nucleus (ARC) plays a major role in the regulation of appetite and food intake $[15,16]$. The pathways of feeding regulation are modulated by the opposing actions of appetite-promoting (orexigenic) neuropeptide Y (NPY)/agouti-related neuropeptide neurons and appetite-inhibiting (anorexigenic) pro-opiomelanocortin (POMC)/cocaine- and amphetamine-regulated transcript neurons, which project from the ARC to the paraventricular nucleus [17-21]. Thus, activation of POMC neurons triggers $\alpha$-melanocyte-stimulating hormone release from POMC axon terminals leading to the suppression of food intake $[21,22]$.

There is strong evidence for diurnal and seasonal variation of Pomc mRNA expression in the hypothalamus of rodents $[23,24]$. Furthermore, in nocturnal animals, POMC derivatives, e.g. adrenocorticotropin and $\beta$-endorphin $(\beta$-END), are not released constitutively, but periodically, resulting in high concentrations of glucocorticoids in the early night $[25,26]$. Thus, in the ARC of rats, Pomc expression follows a diurnal rhythm [27] as well as a circadian rhythm with peak levels at mid-subjective night (CT18) [28], which closely follows the reported pattern of the daily rhythmic activity in $\beta$-END-containing neurons [29]. In rodents, Pomc expression in ARC varies between day and night, and a stimulatory effect of melatonin on Pomc expression in ARC was observed in rats [30] and mice [31]. However, the pathways and messengers that control rhythmic Pomc expression in the hypothalamus are not known in detail.

In order to determine the receptor type through which melatonin controls hypothalamic and hypophysial Pomc expression, we analyzed Pomc expression by means of in situ hybridization in wild-type (WT) and MT1-deficient (MT1-/-) mice at two different time points: mid-subjective day (CT6) and night (CT18). To correlate putative effects of the melatoninergic system on Pomc expression with behavioral data we investigated the feeding pattern, measured the body weight, and compared the latter with the general locomotor activity in both mouse strains. Furthermore, the acute effect of melatonin on Pomc expression was analyzed in WT and MT1-deficient mice after a single melatonin injection at midday.

\section{Materials and Methods}

\section{Animals}

All experiments (Ref. No. F6/19) reported here were conducted in accordance with accepted standards of humane animal care and were consistent with Federal Guidelines and Directive of the European Union (2010/63/EU). Mice with a targeted deletion of the MT1 gene (MT1-/-) and the corresponding WT were bred onto melatonin-proficient $\mathrm{C} 3 \mathrm{H} / \mathrm{HeN}$ background for at least 10 generations $[14,32,33]$. Experiments were performed with adult (10to 18 -week-old) male littermates obtained by heterozygous breeding. Animals were adapted to 12-hour light:12-hour dark (12:12 LD; light phase: $230 \mu \mathrm{W} / \mathrm{cm}^{2}$; dark phase: dim red light $<5 \mu \mathrm{W} /$ $\mathrm{cm}^{2} ;>680 \mathrm{~nm}$ ) standard photoperiod for at least 2 weeks with food and water ad libitum. Lights-off was defined as zeitgeber time (ZT) 12. Two days before tissue collection, animals were transferred to constant darkness. Circadian time 0 was defined as light on at the previous LD schedule. Animals were sacrificed at two different time points (CT6 and CT18).

Recording of Food Intake and Locomotor Activity

Animals were single-housed in standard cages placed in a light-tight ventilated, temperature controlled cabinet under 12:12 LD conditions (lights on from 07:00 to 19:00 h). A digital supervision camera connected to a computer was mounted along the side of the cage and focused on the food container. All mice had ad libitum access to water and pelleted standard mouse chow (Sniff, Soest, Germany). The supervision camera detected movements anywhere in the cage. Images were recorded automatically every minute. Feeding behavior was determined by analyzing the time spent in contact with the food container (CTFC) within 1-hour intervals comparing successive images visually. The total amount of individual food intake per day was assessed by difference in weight of food pellets in the food container of each single cage between the onset and the end of recording divided by the number of days $(n=6)$. The body weight of each mouse was determined after the end of the recording. During the entire time of recording the light-tight cabinet remained closed. The total number of animals used in this experiment was 16 (8 mice/genotype).

In addition, spontaneous locomotor activity was recorded from 3 mice of each genotype. The mice were kept in individual cages equipped with infrared movement detectors linked to an automated recording system (Mouse-E-Motion, Hamburg, Germany). Locomotor activity was continuously recorded during the entire experiment in 10-min intervals. Actograms and activity profiles were created using Clocklab software (Actimetrics, Wilmette, Ill., USA) as described $[34,35]$. The daytime activity was expressed in percent of the total/daily $(24 \mathrm{~h})$ activity as described $[34,36]$.

\section{Melatonin Injection}

Melatonin injections were performed according to the protocol described in Unfried et al. [32]. WT mice were subcutaneously injected once either with $10 \mu \mathrm{g}$ melatonin (Sigma-Aldrich, Schnellendorf, Germany) dissolved in $100 \mu \mathrm{l}$ of $5 \%$ ethanol and $0.9 \%$ $\mathrm{NaCl}$ or with vehicle in the middle of the subjective day (CT6). Four animals per experimental group were sacrificed by decapitation $2.5 \mathrm{~h}$ after the single injection at CT8.5. Brains were immediately frozen in 2-methylbutane (Fluka, Schnellendorf, Germany) placed on dry ice. Pituitaries were dissected out of the sella turcica,
36

Neuroendocrinology 2017;105:35-43

DOI: $10.1159 / 000448333$
Fischer/Mueller/Pfeffer/Wicht/von Gall/ Korf 


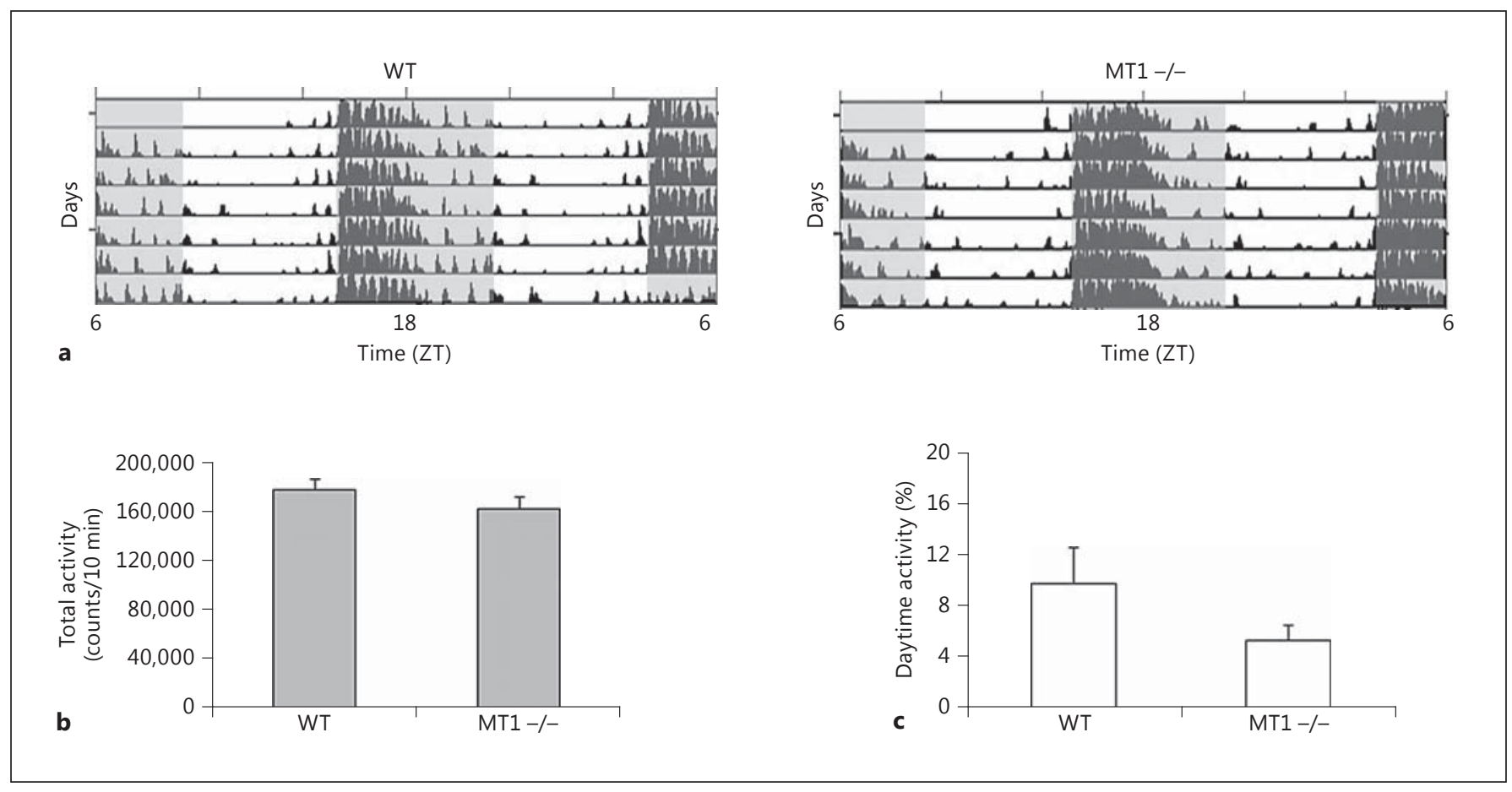

Fig. 1. Analysis of total locomotor activity and daytime locomotor activity in a standard photoperiod. a Double plotted actograms of spontaneous locomotor activity in 12:12 LD conditions from representative WT (left) and MT1-/- (right) mice. Gray shading in-

embedded in Tissue-Tek (Sakura, Alphen aan de Rijn, Netherlands) using vinyl specimen molds (Sakura) and then frozen on dry ice. Tissues were stored at $-80^{\circ} \mathrm{C}$ until cryosectioning.

\section{Cryosectioning}

Tissues embedded in Tissue-Tek were cut into 20 - $\mu$ m-thick frozen sections at $-20^{\circ} \mathrm{C}$ using a cryostat. Brains were cut in the coronal plane and sections were arranged from the rostral to caudal plane on 8 serial SuperFrostPlus glass slides (Menzel-Gläser, Braunschweig, Germany). Pituitaries were cut in the coronal plane on 6 serial slides. Prior to the in situ hybridization, the slides were stored at $-80^{\circ} \mathrm{C}$.

\section{In situ Hybridization}

Radioactive in situ hybridization was carried out with brain and pituitary cryosections of WT and MT1-/- mice (4 mice/genotype and time point) as previously described [32]. The following antisense or the corresponding sense 45-mer probes for Pomc and Npy mRNA expression were used (Pomc sense: $5^{\prime}$-CCA GAG CCG AGT CCA CGC GAG GGC AAG GCG TCC TAC TCC ATG GAG-3'; Pomc antisense: $5^{\prime}$-CTC CAT GGA GTA GGA GCG CTT GCC CTC GCG TGG ACT CGG CTC TGG-3'; Npy sense: $5^{\prime}$ GGG TGT CCC ACC AAT GCA TGC CAC CAC TAG GCT GGA CTC CGC CCC-3' ${ }^{\prime}$, Np $y$ antisense: 5'-GGG GCG GAG TCC AGC CTA GTG GTG GCA TGC ATT GGT GGG ACA GGC-3'). Probes were labeled with $\left[{ }^{33} \mathrm{P}\right] \mathrm{dATP}$ (PerkinElmer, Rodgau, Germany) using a terminal deoxynucleotidyl transferase kit (Invitro- dicates periods of darkness. b Bar plot of overall locomotor activity of WT and MT1-/- mice. c Bar blot of locomotor activity during the light phase of WT and MT1-/- mice. Data are expressed as the mean \pm SEM of 3 animals per genotype.

gen, Karlsruhe, Germany). Following the in situ hybridization procedure, sections were air-dried and exposed to a Kodak BiomaxMR X-ray film (Sigma-Aldrich). Exposure time for the detection of Npy was 10 days and for the detection of Pomc 1 day (pituitaries) or 7 days (brains), respectively. Expression levels were determined by optical density of the autoradiographic signal using ImageJ software and converted into the radioactive value (nCi) by use of ${ }^{14} \mathrm{C}$ microscales (GE Healthcare Biosience, Piscataway, N.J., USA) which were included in each film cassette. Three sections were analyzed per mouse and condition and averaged to obtain a single value for each animal. The tissue-specific autoradiographic signals were assessed as gray-scale units above background (unstained neuropil) within an area of $22,500 \mu \mathrm{m}^{2}$ in the ARC, of $40,000 \mu \mathrm{m}^{2}$ in the pars distalis (PD) or of $16,500 \mu \mathrm{m}^{2}$ in the pars intermedia (PI).

\section{Statistical Analysis}

All data were statistically analyzed using Graph Pad Prism 5 software (San Diego, Calif., USA) by calculating the mean and the corresponding SEM from the entered data. Genotypes and day/ night differences were compared by two-way ANOVA followed by a Bonferroni's comparison of all pairs of columns to assess differences between the genotypes and time points examined. For analysis of locomotor activity rhythms, total food intake and body weight, an unpaired $t$ test was employed after confirming that variances were not significantly different. Values were considered significantly different at $\mathrm{p}<0.05$. 


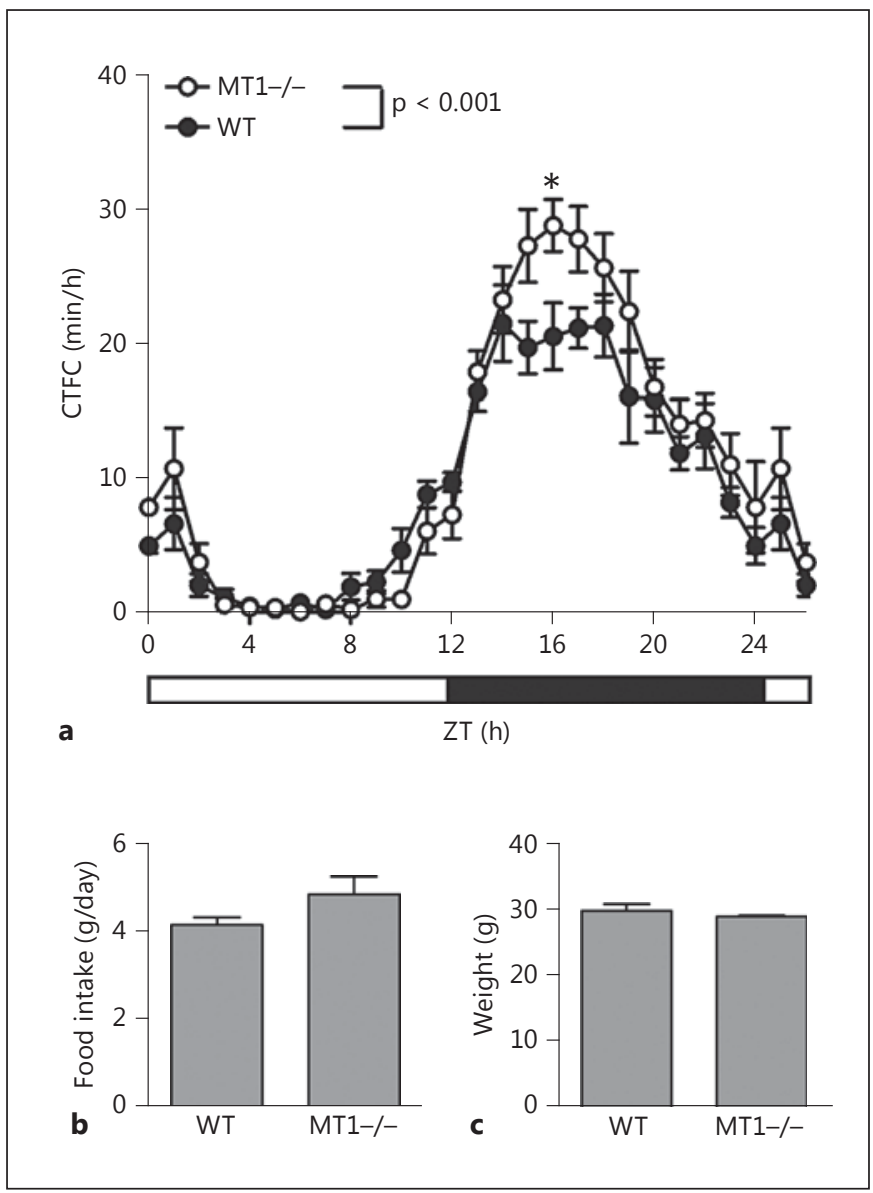

Fig. 2. Feeding behavior, total food intake and body weight of MT1-/- mice and the corresponding WT mice kept under 12:12 LD conditions under ad libitum feeding. a Feeding behavior is expressed as CTFC in 1-hour intervals plotted against ZT from mice with a targeted deletion of the MT1 receptor (MT1-/-) and the corresponding WT littermates. Two-way ANOVA revealed a significant effect of genotype $(\mathrm{p}<0.001)$ and two-way ANOVA followed by Bonferroni's post hoc test revealed a significantly higher peak at ZT16 in feeding behavior of MT1-/- as compared to WT mice. White bar indicates light phase, black bar indicates dark phase. Values are expressed as the mean \pm SEM of 8 animals per genotype and time point. ${ }^{*} \mathrm{p}<0.05$; two-way ANOVA with Bonferroni post hoc test. $\mathbf{b}$ Bar plot of food intake as a measure of the amount of consumed food pellets. Data are expressed as the mean \pm SEM of 8 animals per genotype. c Bar plot of body weight between WT and MT1-/- mice during the whole recording time of 6 successive days.

\section{Results}

WT and MT1-/- mice kept under an LD cycle displayed a clear 24-hour rhythm with expected increased locomotor activity during darkness (fig. 1a). In both genotypes, the activity onset started with the beginning of the dark phase (fig. 1a). The overall spontaneous locomotor activity (mean counts per $10 \mathrm{~min}$ ) did not differ significantly between WT and MT1-/- mice (fig. 1b). Also daytime activity was not significantly different between both genotypes (fig. 1c).

Both genotypes spent very little time in CTFC during the light phase; the main feeding episode occurred in the dark (fig. 2a). Although their activity onsets did not differ, the time patterns of CTFC were significantly different between the two genotypes (two-way ANOVA, effect of genotype, $\mathrm{p}<0.001$ ): the WT mice spent significantly less time in CTFC than the MT1-/- mice ( $<<0.05$; two-way ANOVA followed by the Bonferroni post hoc test, fig. 2a), but there was no significant difference in the total amount of consumed food ( $\mathrm{p}=0.138)$ between MT1-/- mice (4.81 g per day) and WT mice (4.11 g per day) (fig. $2 \mathrm{~b}$ ) or in the body weight $(\mathrm{p}=0.33)$ between WT $(29.78 \mathrm{~g})$ and MT1-deficient (28.85 g) mice (fig. 2c).

To analyze the effects of MT1 receptor-mediated signaling on the hypothalamic POMC/NPY system, Pomc and Npy mRNA expression values were analyzed in the hypothalamic ARC of WT and MT1-/- mice during midsubjective day (CT6, low levels of endogenous melatonin and minimum CTFC) and mid-subjective night (CT18, high levels of endogenous melatonin and maximal CTFC) by in situ hybridization (fig. 3). Specific hybridization signals for Pomc (fig. 3b, d) and Npy (fig. 3a, d) mRNA expression were detected in the ARC of the hypothalamus; the sense controls (fig. 3d) generated no signal. Npy hybridization signals in the ARC did not show a significant difference between mid-subjective night (CT18) and midsubjective day (CT6) in both WT mice and MT1-deficient mice (fig. 3a). In the ARC of WT mice, Pomc hybridization signals were significantly higher at mid-subjective night (CT18) as compared to mid-subjective day (CT6) ( $\mathrm{p}<$ 0.001; two-way ANOVA followed by the Bonferroni post hoc test, fig. 3b). In contrast, in the ARC of MT1-/- mice, no significant difference in the Pomc hybridization signals between CT 6 and CT 18 could be observed and the hybridization signals were significantly lower in MT1-/- mice as compared to WT mice at both time points (fig. 3b).

A specific Pomc hybridization signal was also found in the adenohypophysis (fig. 3c, d). In the PD, Pomc hybridization signals were significantly different between CT6 and CT18 in WT but not in MT1-/- mice (p < 0.001; fig. 3c). Moreover, Pomc values were significantly lower in MT1-/- mice than in WT mice at both time points ( $p<0.001$; fig. 3c). Notably, in the PI there was no significant difference in Pomc hybridization signals between CT6 and CT18 in both genotypes (fig. 3c). 


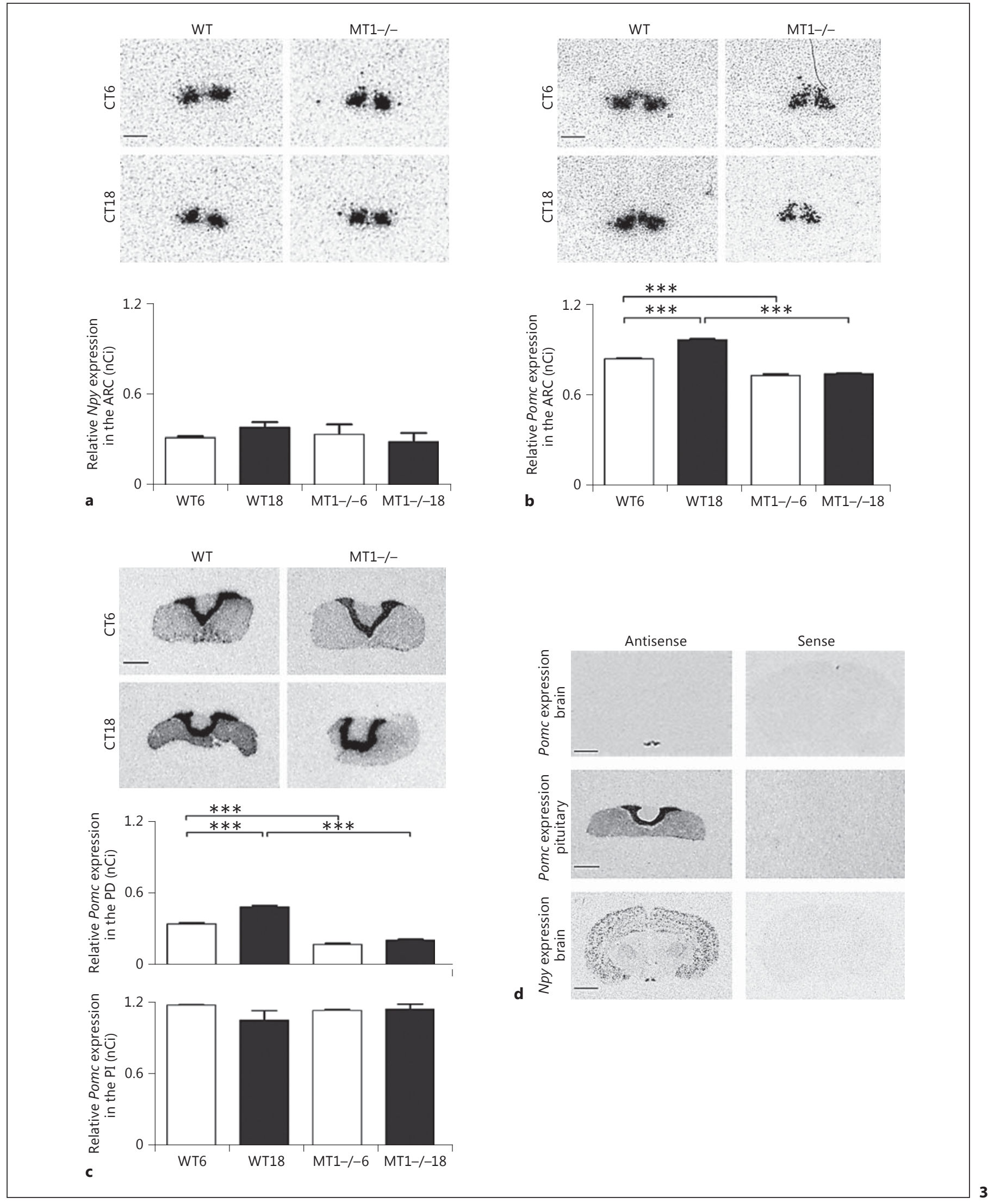

(For legend see next page.) 


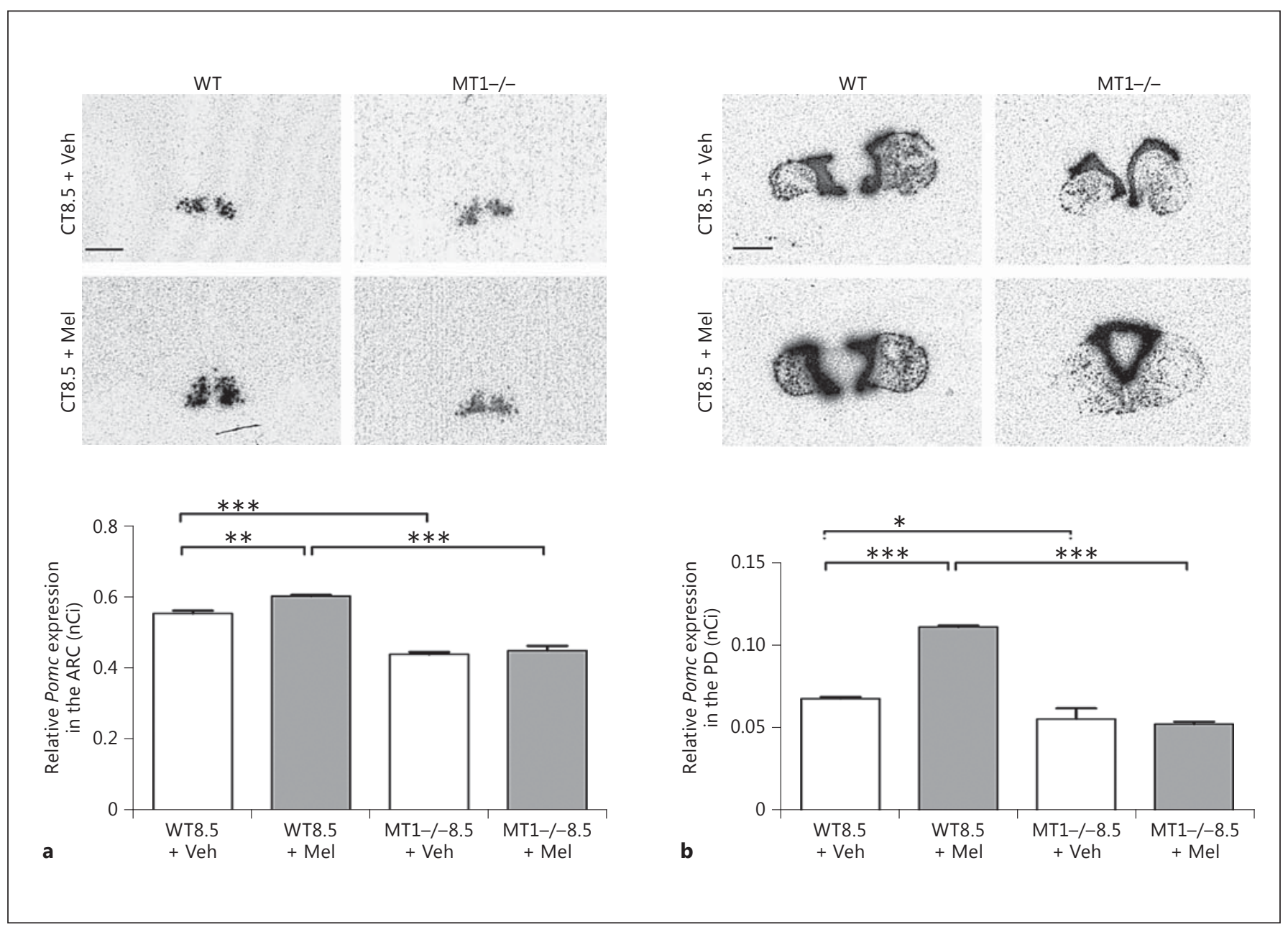

Fig. 4. Effect of exogenous melatonin on Pomc expression in the hypothalamus and pituitary of WT and MT1-/- mice. a Representative autoradiographs and quantification of Pomc hybridization signals in the ARC of WT and MT1-/- mice $2.5 \mathrm{~h}$ after a single melatonin (Mel) or vehicle (Veh) injection at mid-day (CT8.5). Exogenous melatonin applied at mid-subjective day results in an increased Pomc expression in the ARC in WT mice but not in MT1-/- mice. b Representative autoradiographs and quantifica-

Fig. 3. Npy and Pomc expression in the hypothalamus and pituitary of WT and MT1-/- mice at mid-subjective day (CT6) and night (CT18). a Representative autoradiographs of Npy in situ hybridization and quantification in the ARC of WT and MT1-/- mice. Npy hybridization signals are equally high independent of genotype and time point. Scale bar $=200 \mu \mathrm{m}$. b Representative autoradiographs and quantitative analysis of Pomc in situ hybridization in the ARC of WT and MT1-/- mice. In the ARC of WT mice Pomc expression is higher at night than at day. In MT1-/- mice, Pomc expression is not different between day and night and lower as in WT mice. Scale bar $=200 \mu \mathrm{m}$. c Representative autoradiographs and quantitative analysis of Pomc hybridization signals in

tion of Pomc hybridization signals in the PD of the pituitary of WT and MT1-/- mice $2.5 \mathrm{~h}$ after a Mel or Veh injection at mid-day. In the PD Pomc expression was higher after melatonin treatment in WT mice but not in MT1-/- mice. Scale bar $=500 \mu \mathrm{m}$. Values are expressed as the mean \pm SEM of 4 animals per genotype and time point. ${ }^{*} \mathrm{p}<0.05$; $^{* *} \mathrm{p}<0.01$; $^{* *} \mathrm{p}<0.001$; two-way ANOVA with Bonferroni post hoc test.

the PD (upper graph) and PI (lower graph) of the pituitary of WT and MT1-/- mice during day and night. In the PD of WT mice, Pomc expression is higher at night than at day. In MT1-/- mice, Pomc expression is not different between day and night and lower as in WT mice. In contrast, Pomc expression in the PI is not different between day and night independent of genotype. Scale bar = $500 \mu \mathrm{m}$. d Representative autoradiographs of Pomc and Npy antisense and sense hybridization signals in coronal brain and transversal pituitary sections of a WT mouse. Scale bar brain $=2 \mathrm{~mm}$; scale bar pituitary $=500 \mu \mathrm{m}$. Values are expressed as the mean \pm SEM of 3-4 animals per genotype and time point. ${ }^{* * *} \mathrm{p}<0.001$; two-way ANOVA with Bonferroni post hoc test. 
To analyze acute effects of melatonin on Pomc expression in the ARC and adenohypophysis, WT and MT1-/mice received a single melatonin injection at mid-subjective day (CT6) (fig. 4). In both the ARC and the PD of WT mice, hybridization signals of Pomc expression were significantly increased $2.5 \mathrm{~h}$ after an acute single melatonin injection as revealed by two-way ANOVA followed by the Bonferroni post hoc test (ARC: $\mathrm{p}<0.01$, fig. $4 \mathrm{a}$; PD: $\mathrm{p}<$ 0.001 , fig. $4 \mathrm{~b}$ ). In contrast, in MT1-/- mice, the single melatonin injection did not affect Pomc hybridization signals in either the ARC or the PD (fig. 4a, b). These data suggest that the melatonin-induced stimulation of Pomc mRNA expression in both regions is mediated by the MT1 receptor. Again, hybridization signals of Pomc were significantly lower in MT1-/- as compared to WT mice (fig. 4a, b). In both genotypes, melatonin injection did not affect hybridization signals of Pomc in the PI.

\section{Discussion}

The comparison between WT and MT-/- mice presented here demonstrates that MT1-mediated signaling influences feeding behavior. The MT1-/- mice spent significantly more time feeding than the WT mice, while the general locomotor behavior (see also Refinetti [37]), body weight and the total amount of food consumed did not differ between both genotypes. Furthermore, MT1-mediated signaling stimulates Pomc mRNA expression levels in the hypothalamic ARC and the hypophysial PD, but not in the PI. Thus, the MT1-mediated signaling stimulates Pomc expression in a region-specific pattern. Since MT1-dependent increases in Pomc expression levels in the ARC and PD did not elicit direct orexigenic or anorexigenic effects, it is conceivable that MT1-dependent signaling acting on the availability and day/night fluctuations of Pomc expression 'opens the window' for other regulatory processes that occur downstream of Pomc mRNA expression and are independent of MT1.

We found effects of melatonin and the MT1 receptor on the statics and dynamics of the POMC system: the baseline levels of Pomc expression in the ARC were clearly reduced in MT1-/- mice as compared to WT mice. Additionally, Pomc expression of MT1-/- mice does not show day/night differences, whereas Pomc expression levels are significantly increased at night in the ARC of WT mice. This suggests a stimulation of Pomc expression by melatonin acting through the MT1 receptor. Consistently, exogenous melatonin injected during daytime led to an increase in Pomc expression in WT mice but not in

Melatonin Receptor 1 Deficiency Affects Feeding Dynamics and Pomc Expression
MT1-/- mice. These findings are in line with data obtained in rat $[28,30]$ and mice [31].

Our observation that, despite a reduction in Pomc expression levels, food intake is not significantly elevated in C3H MT1-/- mice does not support the notion that hypothalamic POMC neurons generally and exclusively elicit appetite-inhibiting, anorexgenic effects [38]. In this regard, it should be kept in mind that both appetite-promoting, orexigenic (e.g. $\beta$-END) and anorexigenic (e.g. $\alpha$-melanocyte-stimulating hormone) signal peptides may be generated from POMC under the influence of various other regulatory factors, such as endocannabinoids [39], and the cannabinoid 1 (CB1) receptor activation in the hypothalamus increases the release of the orexigenic POMC derivative $\beta$-END in the paraventricular nucleus [40-42]. Hence, it is suggested that the impact of MT1mediated signal transduction pathway on Pomc expression in the ARC probably is not an orexigenic, or anorexigenic signal per se. In accordance with this interpretation, we observed only moderate effects of MT1 deficiency on the food intake. The only significant difference concerned the dynamics of feeding and not the amount of food consumed: MT1-/- mice are 'slow eaters', while the WT mice prefer 'fast food'. This finding is in line with the study of Adamah-Biassi et al. [43] showing that melatonin and the MT1 receptor do not have a major influence on the amount of food ingested but affect the temporal dynamics of food intake and various other behaviors. Also the Pomc expression in the PD was found to be under the stimulatory control of the MT1-signaling pathway, because only WT, but not MT1-/- mice, show nocturnal elevated Pomc expression, and exogenous melatonin injected during daytime stimulates Pomc expression in the PD of WT mice but not of MT1-/- mice.

In contrast to the results obtained in the PD and ARC, the Pomc expression profile of the PI is not significantly regulated by day/night differences or melatonin. Accordingly, our melatonin injection showed no acute effect of exogenously applied melatonin on Pomc expression in this tissue (data not shown). Compared to the clear results in the ARC and PD, it can be suggested that melatonin has no acute effect on Pomc expression in the PI.

An important question relates to the location of the MT1 receptors that mediate Pomc expression in ARC and PD. One possibility may be that the MT1 receptors are located in the ARC itself, since $M t 1$ mRNA and ${ }^{125} \mathrm{I}$-melatonin binding sites have been demonstrated in the ARC of rodents (mouse and rat) [44-46]. On the other hand, a recent study using antibodies against MT1 and MT2 failed to detect these receptors in the rat ARC [47] and

Neuroendocrinology 2017;105:35-43 DOI: $10.1159 / 000448333$ 
also in the sheep ARC, no Mt1 mRNA has been found [48].

Another possibility may be that the melatonin signal affecting the POMC system and thus the Pomc expression in the ARC and PD is decoded in the hypophysial pars tuberalis which contains a high density of MT1 receptors [8] and conveys the MT1-mediated melatonin signal retrogradely via thyrotropin to the hypothalamus including the ARC and anterogradely via endocannabinoids to the PD [14, 32, 49-52].

The possibility that MT1 receptors that control Pomc expression in the PD are located in the PD itself can be ruled out. In the rodent PD (rat and hamster), melatonin binding sites are expressed in the fetus and decline after birth $[53,54]$. Thus, the observed effect of melatonin on Pomc expression could be indirectly mediated by endocannabinoid signals originating from the pars tuberalis [55], as the CB1 receptor is present in the rodent $\mathrm{PD}$ [52].

Surprisingly, the expression levels of the gene encoding for the orexigenic peptide NPY in the ARC did not show a day/night difference in WT mice and also no differences between WT and MT1-/- mice. Thus, the NPYergic orexigenic system in the ARC is not influenced by MT1-dependent signaling in mice. This conforms to observations in Siberian hamsters showing that Npy expres- sion did not change with the photoperiod, i.e., the length of the melatonin $[24,56,57]$. However, other species such as sheep [58] or Spargue-Dawley rats [59] do show a modulation of Npy expression by the photoperiod and the light/dark cycle. Thus, the melatonin-dependent photoperiodic regulation of the orexigenic Npy mRNA appears to be species-specific.

In summary, the present study shows that MT1 receptor deficiency alters the temporal feeding pattern but not the amount of food ingested, and melatonin signaling mediated through the MT1 receptor stimulates Pomc expression in both the ARC and PD of mice.

\section{Acknowledgements}

The authors would like to thank Iris Habazettl for technical support. We thank Marco Koch (Institut für Anatomie, Leipzig, Germany) for helpful discussions, and David R. Weaver (Dept. Neurobiology, UMASS Medical School, Worcester, Mass., USA) for providing breeding pairs of MT1-/- mice.

\section{Disclosure Statement}

The authors have nothing to disclose.

\section{References}

1 Reiter RJ: The melatonin rhythm: both a clock and a calendar. Experientia 1993;49:654-664.

2 Lincoln GA: Melatonin entrainment of circannual rhythms. Chronobiol Int 2006;23:301306.

3 Scherbarth F, Steinlechner SJ: Endocrine mechanisms of seasonal adaptation in small mammals: from early results to present understanding. Comp Physiol B 2010;180:935-952.

4 Steinlechner S: Melatonin as a chronobiotic: PROS and CONS. Acta Neurobiol Exp (Wars) 1996;56:363-372.

5 Jin XW, von Gall C, Pieschl RL, Gribkoff VK, Stehle JH, Reppert SM, Weaver DR: Targeted disruption of the mouse Mel(1b) melatonin receptor. Mol Cell Biol 2003;23:1054-1060.

6 Liu C, Weaver DR, Jin X, Shearman LP, Pieschl RL, Gribkoff VK, Reppert SM: Molecular dissection of two distinct actions of melatonin on the suprachiasmatic circardian clock. Neuron 1997;19:91-102.

7 Roca AL, Godson C, Weaver DR, Reppert SM: Structure, characterization and expression of the gene encoding the mouse Mella melatonin receptor. Endocrinology 1996;138:34693477.

8 von Gall C, Stehle JH, Weaver DR: Mammalian melatonin receptors: molecular biology and signal transduction. Cell Tissue Res 2002a;309:151-162.

9 Hazlerigg DG: What is the role of melatonin within the anterior pituitary? J Endocrinol 2001;170:493-501.

10 Lincoln GA, Anderssib H, Hazlerigg D: Clock genes and the long-term regulation of prolactin secretion: evidence for a photoperiod/circannual timer in the pars tuberalis. J Neuroendocrinol 2003;15:390-397.

11 von Gall C, Garabette ML, Kell CA, Frenzel S, Dehghani F, Schumm-Draeger PM, Weaver DR, Korf HW, Hastings MH, Stehle JH: Rhythmic gene expression in pituitary depends on heterologous sensitization by the neurohormone melatonin. Nat Neurosci 2002;5:234-238.

12 von Gall C, Weaver DR, Moek J, Jilg A, Stehle $\mathrm{JH}$, Korf HW: Melatonin plays a crucial role in the regulation of rhythmic clock gene expression in the mouse pars tuberalis. Ann NY Acad Sci 2005; 1040:508-511.

13 Yasuo S, Yoshimura T, Ebihara S, Korf HW: Photoperiodic control of TSH-beta expression in the mammalian pars tuberalis has different impacts on the induction and suppression of the hypothalamo-hypophysial gonadal axis. J Neuroendocrinol 2009;22:43-50.
14 Unfried C, Burbach G, Korf HW, von Gall C: Melatonin receptor 1-dependent gene expression in the mouse pars tuberalis as revealed by cDNA microarray analysis and in situ hybridization. J Pineal Res 2010;48:148-156.

15 Elmquist JK, Coppari R, Balthasar N, Ichinose M, Lowell BB: Identifying hypothalamic pathway controlling food intake, body weight, and glucose homeostasis. J Comp Neurol 2005; 493:63-71.

16 Sobrino Crespo C, Perjanes Cachero A, Puebla Jimenez L, Barrios V, Arilla F: Peptides and food intake. Front Endocrinol (Lausanne) 2014;5:58.

17 Kalra SP, Kalra PS: Neuropeptide Y: a physiological orexigen modulated by the feedback action of ghrelin and leptin. Endocrinology 2003;22:49-56.

18 O’Rahilly S, Yeo GS, Farooqi IS: Melanocortin receptors weight in. Nat Med 2004;10:351352.

19 Murphy KG, Bloom SR: Gut hormones and the regulation of energy homeostasis. Nature 2006;444:854-859.

20 Higuchi H, Niki T, Shiiya T: Feeding behavior and gene expression of appetite-related neuropeptides in mice lacking for neuropeptide Y Y5. World J Gastroenterol 2008;14:6312-6317. 
21 Dietrich MO, Horvath TL: Hypothalamic control of energy balance: insights into the role of synaptic plasticity. Trends Neurosci 2013;36:65-73.

22 Aponte Y, Atasoy D, Sternson SM: AGRP neurons are sufficient to orchestrate feeding behavior rapidly and without training. Nat Neurosci 2011;14:351-355.

23 Bittman EL, Tubbiola ML, Foltz G, Hegarty CM: Effects of photoperiod and androgen on proopiomelanocortin gene expression in the arcuate nucleus of golden hamster. Endocrinology 1999;140:197-206.

24 Rousseau K, Atcha Z, Cagampang FR, Le Rouzic P, Stirland JA, Ivanov TR, Ebling FJ Klingenspor M, Loudon AS: Photoperiodic regulation of leptin resistance in the seasonally breeding Siberian hamster (Phodopus sungorus). Endocrinology 2002;143:3083-3095.

25 Millington WR, O'Donohue TL, Chappell MC, Roberts JL, Mueller GP: Coordinate regulation of peptide acetyltransferase activity and proopiomelanocortin gene expression in the intermediate lobe of the rat pituitary. Endocrinology 1986;118:2024-2033.

26 Dieckmeis T: Glucocorticoids and the circadian clock. J Endocrinol 2009;200:3-22.

27 Chen CP, Kuhn P, Advis JP, Sarkar DK: Chronic ethanol consumption impairs the circadian rhythm of pro-opiomelanocortin and period genes mRNA expression in the hypothalamus of the male rat. J Neurochem 2004; 88:1547-1554.

28 Seres J, Herichova I, Roman O, Bornstein S, Jurcovicova J: Evidence for daily rhythms of the expression of proopiomelanocortin, interleukin-1-beta and interleukin-6 in adenopituitaries of male long-evans rats: effect of adjuvant arthritis. Neuroimmunomodulation 2004:11:316-322.

29 Jamali KA, Tramu G: Daily cycle of fos expression without hypothalamic POMC neurons of male rat. Brain Res 1997;771:45-54.

30 Yu CX, Wu GC, Xu SF, Chen CH: Melatonin attenuates the intensity of beta-endorphin immunoreactivity in the arcuate nucleus of rat hypothalamus. Sheng Li Xue Bao 2000;52: 263-266.

31 Wei YM, Xu Y, Yu CX, Han J: Melatonin enhances the expression of $\beta$-endorphin in hypothalamic arcuate nucleus of morphine-dependent mice. Sheng Li Xue Bao 2009;61:255262.

32 Unfried C, Ansari N, Yasuo S, Korf HW, von Gall C: Impact of melatonin and molecular clockwork components on the expression of thyrotropin beta-chain (Tshb) and the Tsh receptor in the mouse pars tuberalis. Endocrinology 2009;150:4653-4662.

33 Fischer C, Christ E, Korf HW, von Gall C: Tafa-3 encoding for a secretory peptide is expressed in the mouse pars tuberalis and is affected by melatonin 1 receptor deficiency. Gen Comp Endocrinol 2012;177:98-103.

34 Pfeffer M, Rauch A, Korf HW, von Gall C: The endogenous melatonin signal facilitates reentrainment of the circadian system to light-in- duced phase advances by acting upon MT2 receptors. Chronobiol Int 2012;29:415-429.

35 Pfeffer M, Plenzig S, Gispert S, Wada K, Korf HW, von Gall C: Disturbed sleep/wake rhythms and neuronal cell loss in lateral hypothalamus and retina of mice with a spontaneous deletion in the ubiquitin carboxyl-terminal hydrolase L1 gene. Neurobiol Aging 2012; 33:393-403.

36 Homola M, Pfeffer M, Fischer C, Zimmermann H, Robson SC, Korf HW: Expression of ectonucleotidases in the prosencephalon of melatonin-proficient $\mathrm{C} 3 \mathrm{H}$ and melatonin-deficient $\mathrm{C} 57 \mathrm{Bl}$ mice: spatial distribution and time-dependent changes. Cell Tissue Res 2015;362:163-176.

37 Refinetti R: Compression and expansion of circadian rhythm in mice under long and short photoperiods. Integr Physiol Behav Sci 2002;37:114-127.

38 Ramos EJ, Mequid MM, Campos AC, Coelho JC: Neuropeptide Y, alpha-melanocyte-stimulation hormone, and monoamines in food intake regulation. Nutrition 2005;21:269-279.

39 Rorato R, Miyahara C, Antunes-Rodrigues J, Elias LLK: Tolerance to hypophagia induced by prolonged treatment with a CB1 antagonist is related to the reversion of anorexigenic neuropeptide gene expression in the hypothalamus. Regul Pept 2013;182:12-18.

40 Koch M, Varela L, Kim JG, Kim JD, Hernandez-Nuno F, Simonds SE, Castorena CM, Vianna CR, Elmquist JK, Morozov YM, Rakic P, Bechmann I, Cowley MA, Szigeti-Buck K, Dietrich MO, Gao XB, Diano S, Horvath TL: Hypothalamic neurons promote cannabinoidinduced feeding. Nature 2015;519:45-50.

41 Dube MG, Horvath TL, Leranth C, Kalra PS, Kalra SP: Naloxone reduces the feeding evoked by intracerebroventricular galanin injection. Physiol Behav 1994;56:811-813.

42 Kalra SP, Horvath TL: Neuroendocrine interactions between galanin, opiods, and neuropeptide $\mathrm{Y}$ in the control of reproduction and appetite. Ann NY Acad Sci 1998;863:236-240.

43 Adamah-Biassi EB, Hudson RL, Dubocovich ML: Genetic deletion of MT1 melatonin receptors alters spontaneous behavioral rhythms in male and female C57BL/6 mice. Horm Behav 2014;664:619-627.

44 Reppert SM, Weaver DR, Ebisawa T: Cloning and characterization of a mammalian melatonin receptor that mediates reproductive and circadian response. Neuron 1994;13:11771185.

45 Drew JE, Barrett P, Mercer JG, Moar KM, Canet E, Delagrange P, Morgan PJ: Localization of the melatonin-related receptor in the rodent brain and peripheral tissues. J Neuroendocrinol 2001;13:453-458.

46 Williams LM, Hannah LT, Hastings MH, Maywood ES: Melatonin receptors in the rat brain and pituitary. J Pineal Res 1995;19:173177.

47 Lacoste B, Angeloni D, Dominguez-Lopez S, Calderoni S, Mauro A, Fraschini F, Descarries L, Gobbi G: Anatomical and cellular localiza- tion of melatonin MT1 and MT2 receptors in the adult rat brain. J Pineal Res 2015;58:397417.

48 Li Q, Rao A, Pereira A, Clarke IJ, Smith JT: Kisspeptin cells in the ovine arcuate nucleus express prolactin receptor but not melatonin receptor. J Neuroendocrinol 2011;259:834-843.

49 Hanon EA, Lincoln GA, Fustin JM, Dardente $\mathrm{H}$, Masson-Pevet M, Morgan PJ, Hazlerigg DG: Ancestral TSH mechanism signals summer in a photoperiodic mammal. Curr Biol 2008;18:1147-1152.

50 Nakao N, Ono H, Yamamura T, Anraku T, Takagi T, Higashi K, Yasuo S, Katou Y, Kageyama S, Uno Y, Kasukawa T, Iigo M, Sharp PJ, Iwasawa A, Suzuki Y, Sugano S, Niimi T, Mizutani M, Namikawa T, Ebihara S, Ueda HR, Yoshimura T: Thyrotrophin in the pars tuberalis triggers photoperiodic response. Nature 2008;452:317-322.

51 Ono $\mathrm{H}$, Hoshino $\mathrm{Y}$, Yasuo S, Watanabe M, Nakane Y, Murai A, Ebihara S, Korf HW, Yoshimura T: Involvement of thyrotropin in photoperiodic signal transduction in mice. Proc Natl Acad Sci USA 2008;105:18238-18242.

52 Yasuo S, Koch M, Schmidt H, Ziebell S, Bojunga J, Geisslinger G, Korf HW: An endocannabinoid system is localized to the hypophysial pars tuberalis of Syrian hamsters and responds to photoperiodic changes. Cell Tissue Res 2010;340:127-136.

53 Vanecek J, Pavlik A, Illnerova H: Hypothalamic melatonin receptor sites revealed by autoradiograph. Brain Res 1988;435:359-362.

54 Johnston JD, Messager S, Barrett P, Hazlerigg DG: Melatonin action in the pituitary: neuroendocrine synchronizer and developmental modulator? J Neuroendocrinol 2003;15:405408.

55 Yasuo S, Korf HW: The hypophysial pars tuberalis transduces photoperiodic signals via multiple pathways and messenger molecules. Gen Comp Endocrinol 2011;1721:15-22.

56 Reddy AB, Cronin AS, Ford H, Ebling FJ: Seasonal regulation of food intake and body weight in the male Siberian hamster: studies of hypothalamic orexin (hypocretin), neuropeptide Y (NPY) and pro-opiomelanocortin (POMC). Eur J Neurosci 1999;11:3255-3264.

57 Mercer JG, Moar KM, Logie TJ, Findlay PA, Adam CL, Morgan PJ: Seasonally inappropriate body weight induced by food restriction: effect on hypothalamic gene expression in male Siberian hamsters. Endocrinology 2001; 142:4173-4181.

58 Clarke IJ, Scott CJ, Rao A, Pompolo S, BarkerGibb ML: Seasonal changes in the expression of neuropeptide $\mathrm{Y}$ and pro-opiomelanocortin mRNA in the arcuate nucleus of the ovariectomized ewe: relationship to the seasonal appetite and breeding cycles. J Neuroendocrinol 2000;12:1105-1111.

59 Akabayashi A, Levin N, Paez X, Alexander JT, Leibowitz SF: Hypothalamic neuropeptide Y and its gene expression: relation to light/dark cycle and circulating corticosterone. Mol Cell Neurosci 1994;5:210-218.
Melatonin Receptor 1 Deficiency Affects Feeding Dynamics and Pomc Expression
Neuroendocrinology 2017;105:35-43 DOI: $10.1159 / 000448333$ 